Witnessing Girlhood 



\title{
Witnessing Girlhood
}

Toward an Intersectional Tradition

\author{
of Life Writing
}

Leigh Gilmore and Elizabeth Marshall

F O R D H M UN IVERS ITY PRES S

New York 2019 
Copyright (C) 2019 Fordham University Press

All rights reserved. No part of this publication may be reproduced, stored in a retrieval system, or transmitted in any form or by any means-electronic, mechanical, photocopy, recording, or any other-except for brief quotations in printed reviews, without the prior permission of the publisher.

Fordham University Press has no responsibility for the persistence or accuracy of URLs for external or third-party Internet websites referred to in this publication and does not guarantee that any content on such websites is, or will remain, accurate or appropriate.

Fordham University Press also publishes its books in a variety of electronic formats. Some content that appears in print may not be available in electronic books.

Visit us online at www.fordhampress.com.

Library of Congress Cataloging-in-Publication Data available online at https://catalog.loc.gov.

Printed in the United States of America

$$
\begin{gathered}
2 \text { I } 20 \text { I9 } 5432 \text { I } \\
\text { First edition }
\end{gathered}
$$


for

Maisie Katbryn Meneer

William Gilmore Pounds

Finn Gilmore Pounds 
